\title{
Measurement of natural radionuclides and dose assessment of granites from Ondo State, Nigeria
}

\author{
J.A. ADEMOLA ${ }^{1}$, A.A. AYENI ${ }^{1}$
}

(Manuscript received 10 May 2010, accepted 29 June 2010)

ABSTRACT The activity concentrations of ${ }^{226} \mathrm{Ra},{ }^{232} \mathrm{Th}$ and ${ }^{40} \mathrm{~K}$ in fifty granite samples collected from five different quarry industries in Ondo State, Nigeria, were determined using gamma-ray spectrometry. The mean activity concentrations for each industry ranged from 16.7(6.4) to $85.4(23.0)$, $62.4(10.1)$ to $113.6(7.6)$, and $1315(136)$ to $1551(84) \mathrm{Bq} \cdot \mathrm{kg}^{-1}$ for ${ }^{226} \mathrm{Ra},{ }^{232} \mathrm{Th}$ and ${ }^{40} \mathrm{~K}$, respectively. The values in parenthesis are the standard deviations. When compared with results from some parts of the world, the ${ }^{226} \mathrm{Ra}$ and ${ }^{232} \mathrm{Th}$ contents were lower, whereas the ${ }^{40} \mathrm{~K}$ content was similar. Using different approaches to estimate the potential radiological hazard of the samples, the results obtained were below the recommended maximum limits. This shows that the radiological hazards associated with the use of the granites examined in this study as building material are within the acceptable limit.

Keywords: Natural radionuclides / granite / dose assessment / Ondo State

RÉSUMÉ Mesure des radionucléides naturels et de l'évaluation de la dose de granits de l'État d'Ondo, Nigéria.

Les concentrations en ${ }^{226} \mathrm{Ra},{ }^{232} \mathrm{Th}$ et ${ }^{40} \mathrm{~K}$ ont été déterminées par spectrométrie gamma dans cinquante échantillons de granit collectés dans cinq carrières différentes de l'État d'Ondo, Nigeria. La concentration moyenne en ${ }^{226} \mathrm{Ra},{ }^{232} \mathrm{Th}$ et ${ }^{40} \mathrm{~K}$ varie respectivement pour chaque carrière de $16,7(6,4)$ à $85,4(23,0)$, de $62,4(10,1)$ à $113,6(7,6)$ et de $1315(136)$ à $1551(84) \quad B q \cdot \mathrm{kg}^{-1}$. Les valeurs entre parenthèse sont les déviations standards. Lorsqu'elles sont comparées à des résultats obtenus dans d'autres parties du monde, les valeurs en ${ }^{226} \mathrm{Ra}$ et en ${ }^{232} \mathrm{Th}$ sont plus petites alors qu'elles sont semblables pour le ${ }^{40} \mathrm{~K}$. Les résultats obtenus en utilisant différentes approches pour estimer le détriment radiologique potentiel des échantillons, sont inférieurs aux limites maximales recommandées. Ceci montre que les risques radiologiques associés à l'utilisation des granits étudiés dans cette étude comme matériau de construction, sont inférieurs à la limite acceptable.

\section{Introduction}

Naturally occurring radionuclides of terrestrial origin (also known as primordial radionuclides) are present in various concentrations in all media in the environment. Gamma radiations from these radionuclides, which are characterised

\footnotetext{
1 Department of Physics, University of Ibadan, Ibadan, Nigeria.
} 
by long lives comparable with the age of the earth, and their progeny are an important external source of radiation. Among these radionuclides are ${ }^{40} \mathrm{~K},{ }^{238} \mathrm{U}$ and ${ }^{232} \mathrm{Th}$. Most natural rocks contain ${ }^{40} \mathrm{~K}$ and the decay series of ${ }^{238} \mathrm{U}$ and ${ }^{232} \mathrm{Th}$. The concentrations of natural radionuclides in rocks vary considerably depending on the rock formation and lithologic character (Anjos et al., 2005; Abd and Saleh, 2003; Arafa, 2004).

Granite is an acidic form of igneous rock. It is hard and tough with an average density of $2.75 \mathrm{~g} / \mathrm{cm}^{3}$. Its colour varies from pink to grey or black depending on the chemistry and mineralogy. Granite consists of coarse grains of quartz (10-50\%), potassium feldspars and sodium feldspar. These minerals make up $80 \%$ of the rock; other minerals include mica (muscovite and biotite) and hornblende. Granite is usually suitable as a building or ornamental material for interior and exterior use. The use of granite as a building material has increased in the last few years and the global amount of production is comparable with that of marble (Pavlidou et al., 2006). Different types of building materials have been tested for their radioactivity. The use of building materials can increase the radiation exposure of the population appreciably if the natural radionuclide levels are above normal.

Some granites have been reported to have a high level of radioactivity, thereby raising concerns about their radiological implications. Buildings located over granite may give rise to high doses of radiation, and cellars and basements sunk into the soil over granite can become a trap for radon gas, which is formed by the decay of uranium. Radon can also be introduced into houses by wells drilled into granite.

The demand for granite in the Nigerian commercial market is increasing with little or no knowledge of the health implications associated with its use as far as radiation is concerned. Hence this study aimed to determine naturally occurring radionuclides in granites collected from five prominent quarry industries in Ondo State, Nigeria. The activity concentrations of natural radionuclides in these granites are compared with similar data in the literature. The potential radiological hazards of the samples are estimated using different approaches.

\section{Materials and methods}

Fifty rock samples were collected, ten from each of five government-registered quarry industries in Ondo State, Nigeria. The quarries include Setraco and $\mathrm{Mol}$ in Ore, Japaul and Serena in Ifon, and Atlor in Akure. Figure 1 is a map of Ondo state showing the study locations. Each sample was packed in a nylon bag and labelled. The samples were pulverised and oven-dried at a temperature of $100{ }^{\circ} \mathrm{C}$ in order 


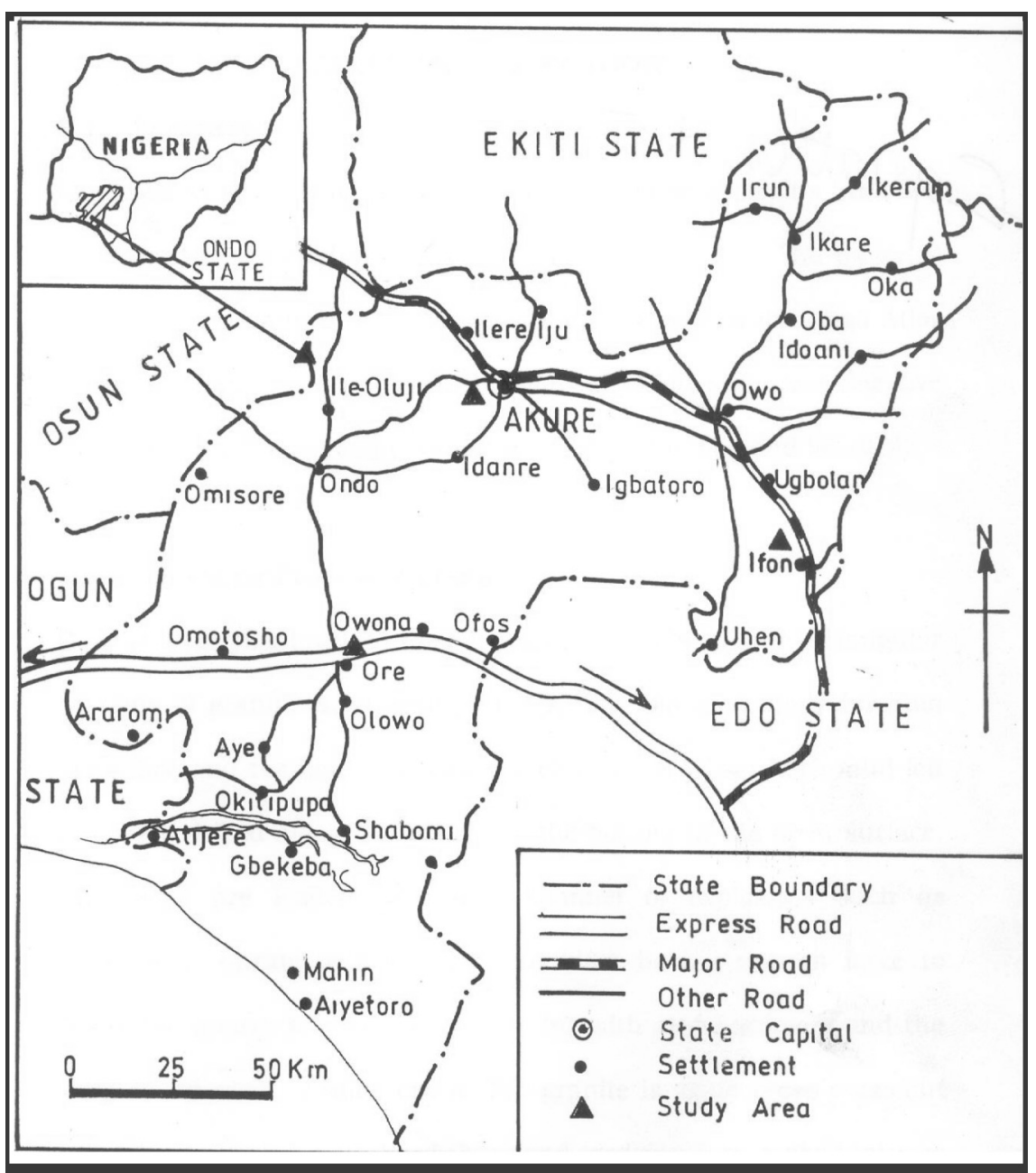

Figure 1 - Map of Ondo State showing the study area (Ore, Ifon and Akure).

Carte de l'État d'Ondo montrant la zone étudiée (Ore, Ifon et Akure).

to attain a constant mass. A mass of $200 \mathrm{~g}$ of each of the dried samples was packed into plastic containers. The containers were sealed, labelled and stored for more than four weeks in order to allow the in-growth of uranium and thorium decay products and achievement of equilibrium of ${ }^{238} \mathrm{U}$ and ${ }^{232} \mathrm{Th}$ with their respective progeny. 
Measurement of activity concentrations was carried out using a lead-shielded $76 \mathrm{~mm} \times 76 \mathrm{~mm} \mathrm{NaI}(\mathrm{Tl})$ (Model No. 1102 series) scintillation detector sealed with a photomultiplier tube and coupled to a Canberra series 10 plus multichannel analyser (MCA) through a preamplifier. The detector has a resolution of about $8 \%$ at energy of $0.662 \mathrm{MeV}\left({ }^{137} \mathrm{Cs}\right)$, which is considered adequate to distinguish the gamma-ray energies of interest in the present study. Energy calibration was done using gamma sources from Nucleus Inc., Oak Ridge, TN, USA. The detection efficiency calibration of the system was carried out using the reference standard source prepared from Rocketdyne Laboratories, Canoga Park, California, USA, which is traceable to a mixed standard source by Analytic Inc., Atlanta, Georgia. The containers containing the samples were placed directly on the top of the detector and counted for a period of 36000 seconds. The net area under the photopeak was related to the detection efficiency $E_{p}$ through equation (1) (Farai and Ademola, 2005)

$$
E_{p}=\frac{A}{t c y m}
$$

where $t$ is the counting time, $c$ is the activity concentration in Bq. $\mathrm{kg}^{-1}, y$ is the gamma yield and $m$ is the mass of the sample. The radium content of the samples was determined from the intensity of the $1.765 \mathrm{MeV}$ photopeak of ${ }^{214} \mathrm{Bi}$. The thorium content was determined from the $2.610 \mathrm{MeV}$ photopeak of ${ }^{208} \mathrm{Tl}$ and the potassium content from the $1.465 \mathrm{MeV}$ photopeak following the decay of ${ }^{40} \mathrm{~K}$.

\section{Results and discussion}

\subsection{Activity concentration}

The ranges and mean activity concentrations of ${ }^{226} \mathrm{Ra},{ }^{232} \mathrm{Th}$ and ${ }^{40} \mathrm{~K}$ in granites collected from each of the industries are presented in Table I. The highest concentrations of ${ }^{226} \mathrm{Ra},{ }^{232} \mathrm{Th}$ and ${ }^{40} \mathrm{~K}$ were 85.4(23.0) (Setraco), 113.6(7.9) (Atlor) and 1551(84) Bq.kg ${ }^{-1}$ (Serena), respectively, while the lowest were 16.7(6.4) (Atlor), 62.4(10.1) (Mol) and 1315(136) Bq. kg ${ }^{-1}$ (Setraco). The values in parenthesis are the standard deviations. All the mean values of activity concentration of the granites investigated in this study for ${ }^{232} \mathrm{Th}$ and ${ }^{40} \mathrm{~K}$ were higher than the corresponding typical world averages of 50 and $500 \mathrm{~Bq} \cdot \mathrm{kg}^{-1}$, respectively, for building materials (UNSCEAR, 1993). For ${ }^{226} \mathrm{Ra}$, the mean values obtained for three of the granite industries were higher than the corresponding typical world average of $50 \mathrm{~Bq} \cdot \mathrm{kg}^{-1}$ for building materials (UNSCEAR, 1993), whereas the mean values for two of the industries were lower.

${ }^{40} \mathrm{~K}$ concentrations were similar to the activity concentrations of granites from some other parts of the world, whereas the activity concentrations of ${ }^{226} \mathrm{Ra}$ and ${ }^{232}$ Th were lower (Tab. II). 
TABLE I

Activity concentrations of ${ }^{226} \mathrm{Ra},{ }^{232} \mathrm{Th}$ and ${ }^{40} \mathrm{~K}$ in granite samples. Concentrations en ${ }^{226} \mathrm{Ra},{ }^{232} \mathrm{Th}$ et ${ }^{40} \mathrm{~K}$ dans les échantillons de granit.

\begin{tabular}{lccccccc}
\hline \multirow{2}{*}{ Industry } & \multirow{2}{*}{ No. of samples } & \multicolumn{2}{c}{${ }^{226} \mathrm{Ra}\left(\mathrm{Bq} \cdot \mathrm{kg}^{-1}\right)$} & \multicolumn{2}{c}{${ }^{232} \mathrm{Th}\left(\mathrm{Bq} \cdot \mathrm{kg}^{-1}\right)$} & \multicolumn{2}{c}{${ }^{40} \mathrm{~K}\left(\mathrm{~Bq} \cdot \mathrm{kg}^{-1}\right)$} \\
& & Mean(SD) & Range & Mean(SD) & Range & Mean(SD) & Range \\
\hline Setraco & 10 & $85.4(23.0)$ & $55.5-119.9$ & $87.4(8.1)$ & $72.3-96.4$ & $1315(136)$ & $1128-1535$ \\
Mol & 10 & $22.9(7.9)$ & $5.8-35.2$ & $62.4(10.1)$ & $52.8-87.0$ & $1427(113)$ & $1135-1530$ \\
Japaul & 10 & $52.4(10.8)$ & $42.3-77.7$ & $65.9(6.6)$ & $53.2-78.5$ & $1358(41)$ & $1310-1430$ \\
Serena & 10 & $59.3(11.4)$ & $36.3-75.4$ & $87.2(8.2)$ & $75.5-103.7$ & $1551(84)$ & $1374-1620$ \\
Atlor & 10 & $16.7(6.4)$ & $7.1-29.1$ & $113.6(7.9)$ & $103.0-123.2$ & $1478(70)$ & $1391-1595$ \\
\hline
\end{tabular}

SD denotes standard deviation.

\section{TABLE II}

Average values of activity concentrations of ${ }^{226} \mathrm{Ra},{ }^{232} \mathrm{Th}$ and ${ }^{40} \mathrm{~K}\left(\mathrm{~Bq} \cdot \mathrm{kg}^{-1}\right)$ in granite samples from some countries of the world.

Valeurs moyennes des concentrations en ${ }^{226} \mathrm{Ra},{ }^{232} \mathrm{Th}$ et ${ }^{40} \mathrm{~K}\left(\mathrm{~Bq} \cdot \mathrm{kg}^{-1}\right)$ dans des échantillons de granit provenant de différentes parties du monde.

\begin{tabular}{lccccl}
\hline Country/origin & No. of samples & ${ }^{226} \mathrm{Ra}$ & ${ }^{232} \mathrm{Th}$ & ${ }^{40} \mathrm{~K}$ & Reference \\
\hline Brazil & 14 & 82 & 168 & 1297 & Tzortzis, 2003 \\
China & 8 & 95 & 158 & 1256 & Chen and Lin, 1996 \\
Egypt/Um Taghir & 39 & 558 & 359 & 3918 & El-Arabi, 2007 \\
Finland & 3 & 94 & 163 & 1223 & Chen and Lin, 1996 \\
Italy & 4 & 64 & 91 & 1206 & Ménager et al., 1993 \\
Turkey/Kaymaz & 7 & 306 & 248 & 1266 & Orgun and Altinsoy, 2005 \\
Pakistan/AGC & 20 & 659 & 598 & 1203 & Asghar et al., 2008 \\
Ondo/Nigeria & 50 & 47 & 83 & 1426 & Present study \\
\hline
\end{tabular}

\subsection{Radium equivalent activity}

Radium equivalent activity is used to compare the activity concentrations of ${ }^{226} \mathrm{Ra},{ }^{232} \mathrm{Th}$ and ${ }^{40} \mathrm{~K}$ in building materials. It is based on the estimation that $370 \mathrm{~Bq} \cdot \mathrm{kg}^{-1}$ of ${ }^{226} \mathrm{Ra}, 259 \mathrm{~Bq} \cdot \mathrm{kg}^{-1}$ of ${ }^{232} \mathrm{Th}$ and $4810 \mathrm{~Bq} \cdot \mathrm{kg}^{-1}$ of ${ }^{40} \mathrm{~K}$ produce the same gamma dose rate (Beretka and Mathew, 1985; Arafa, 2004). The radium equivalent can be estimated using the equation (Beretka and Mathew, 1985; Ademola and Atare, 2010)

$$
R a_{e q}=A_{R a}+1.43 A_{T h}+0.077 A_{K}
$$

where $A_{R a}, A_{T h}$ and $A_{K}$ are the activity concentrations of ${ }^{226} \mathrm{Ra},{ }^{232} \mathrm{Th}$ and ${ }^{40} \mathrm{~K}$, respectively, in Bq. $\mathrm{kg}^{-1}$. For materials such as granite to be suitable for construction 
TABLE III

Radium equivalent activity $R a_{e q}$, external radiation hazard index $H_{e x t}$, activity concentration index $I$, absorbed dose rate $D$ and annual effective dose $E$ of granite samples.

Activité équivalente en radium $R a_{e q}$, indice de détriment radiologique externe $H_{e x t}$, Indice de concentration $I$, débit de dose absorbée $D$ et dose effective annuelle $E$ des échantillons de granit.

\begin{tabular}{lcccccccccc}
\hline \multirow{2}{*}{ Industry } & \multicolumn{2}{c}{$R a_{e q}\left({\left.\mathrm{~Bq} \cdot \mathrm{kg}^{-1}\right)}\right.$} & \multicolumn{2}{c}{$H_{e x}$} & \multicolumn{2}{c}{$I$} & \multicolumn{2}{c}{$D\left(\mu \mathrm{Gy} \cdot \mathrm{h}^{-1}\right)$} & \multicolumn{2}{c}{$E(\mathrm{mSv})$} \\
& Mean(SD) & Range & Mean(SD) & Range & Mean(SD) & Range & Mean(SD) & Range & Mean(SD) & Range \\
\hline Setraco & $312(33)$ & $263-357$ & $0.84(0.09)$ & $0.71-0.97$ & $1.19(0.17)$ & $0.98-1.54$ & $0.035(0.004)$ & $0.029-0.041$ & $0.17(0.02)$ & $0.14-0.19$ \\
Mol & $222(14)$ & $203-242$ & $0.60(0.04)$ & $0.55-0.65$ & $0.86(0.05)$ & $0.79-0.94$ & $0.025(0.002)$ & $0.023-0.028$ & $0.12(0.01)$ & $0.11-0.13$ \\
Japaul & $251(15)$ & $220-275$ & $0.68(0.04)$ & $0.60-0.74$ & $0.96(0.05)$ & $0.85-1.04$ & $0.029(0.002)$ & $0.025-0.031$ & $0.14(0.01)$ & $0.12-0.15$ \\
Serena & $303(14)$ & $287-331$ & $0.84(0.05)$ & $0.78-0.96$ & $1.15(0.05)$ & $1.09-1.25$ & $0.034(0.002)$ & $0.032-0.037$ & $0.17(0.01)$ & $0.16-0.18$ \\
Atlor & $293(15)$ & $265-312$ & $0.79(0.04)$ & $0.72-0.84$ & $1.12(0.06)$ & $1.01-1.18$ & $0.032(0.002)$ & $0.029-0.034$ & $0.16(0.01)$ & $0.14-0.17$
\end{tabular}

SD denotes standard deviation.

purposes in terms of radiological hazard the radium equivalent activity must not exceed $370 \mathrm{~Bq} \cdot \mathrm{kg}^{-1}$. This amount is equivalent to a radiation dose rate of $1.5 \mathrm{mGy}^{-1} \mathrm{y}^{-1}$ (Krisiuk et al., 1971; Krieger, 1981). The $R a_{e q}$ was calculated using the activity concentrations and the results are presented in Table III. The results obtained show that $R a_{e q}$ of all the samples considered in this study are less than the recommended limit of $370 \mathrm{~Bq} \cdot \mathrm{kg}^{-1}$. Hence the external annual dose rate of natural radionuclides in the granite samples does not exceed $1.5 \mathrm{mGy}$, and therefore poses no significant radiation hazard when used for the construction of dwellings.

\subsection{External radiation hazard index}

Several authors have proposed formulae to estimate the external radiation hazard index of building materials (Mamont-Ceisla et al., 1981; Lindell, 1984; DIH, 1986). The external hazard index of the granite samples considered in this study was calculated using the relation (Beretka and Mathew, 1985; Krieger, 1981; Ademola and Atare, 2010)

$$
H_{\text {ext }}=\frac{A_{R a}}{370}+\frac{A_{T h}}{259}+\frac{A_{K}}{4810} \leq 1
$$

where $A_{R a}, A_{T h}$ and $A_{K}$ are the activity concentrations of ${ }^{226} \mathrm{Ra},{ }^{232} \mathrm{Th}$ and ${ }^{40} \mathrm{~K}$ in Bq. $\mathrm{kg}^{-1}$, respectively. The activity limit in terms of $H_{\text {ext }}$ is 1 for safe use of a material in building construction. The calculated results of the external radiation hazard index are presented in Table III. The mean values ranged from 0.60 to 0.84 . All of the granite samples studied in this work had $H_{\text {ext }}$ less than 1 . This implies that the radiological hazard associated with the studied samples as building materials is not significant. 
TABLE IV

Activity concentration index values suggested by the European Commission (EC, 1999), taking into account typical ways and amounts in which the material is used in a building.

Valeurs de l'Indice de concentration suggérées par la Commission Européenne (EC, 1999) prenant en compte les quantités et façons typiques dans lesquels ce matériau est utilisé en construction.

\begin{tabular}{lcc}
\hline Dose criterion & $0.3 \mathrm{mSv}_{\mathrm{y}} \mathrm{y}^{-1}$ & $1 \mathrm{mSv}^{-1} \mathrm{y}^{-1}$ \\
\hline Materials used in bulk amounts, e.g. concrete & $I \leq 0.5$ & $I \leq 1$ \\
Superficial and other materials with restricted use: tiles, boards, etc. & $I \leq 2$ & $I \leq 6$ \\
\hline
\end{tabular}

\subsection{Activity concentration index}

For building materials, investigation levels can be derived for practical monitoring purposes. It is practical to present investigation levels in the form of an activity concentration index, $I$, because more than one radionuclide contributes to the dose. The activity concentration index takes into account typical ways and amounts in which the material is used in a building (EC, 1999). The activity concentration index, $I$, is derived to indicate whether the annual dose due to the excess external gamma radiation in a building may exceed $1 \mathrm{mSv}$ and is given as (EC, 1999)

$$
I=\frac{A_{R a}}{300}+\frac{A_{T h}}{200}+\frac{A_{K}}{3000}
$$

where $A_{R a}, A_{T h}$ and $A_{K}$ are the activity concentrations of radium, thorium and potassium in Bq. $\mathrm{kg}^{-1}$, respectively. The activity concentration index shall not exceed the values presented in Table IV depending on the dose criterion and the amount and way the material is used in a building. For superficial and other building materials with restricted fractional mass usage, such as granite, the exemption dose criterion $\left(0.3 \mathrm{mSv} \cdot \mathrm{y}^{-1}\right)$ corresponds to an activity concentration index $I \leq 2$, while the dose criterion of $1 \mathrm{mSv} \mathrm{y}^{-1}$ is met for $I \leq 6$ (EC, 1999). The activity concentration index values of the samples are presented in Table III. The mean values varied between $0.86(0.05)(\mathrm{Mol})$ and $1.19(0.17)$ (Setraco). In view of the use of granites in building construction in Nigeria, none of the samples exceeded the recommended upper limit or recommended exemption level for exposure to external gamma radiation.

\subsection{Absorbed dose rate and annual effective dose}

According to EC (1999), the absorbed dose rate in a room can be calculated for building materials using a specific dose rate. For superficial materials such as 
marble, ceramic, granite and roofing tile, the dose rate is given as (Krstić et al., 2007)

$$
D\left(\mathrm{nGy} \cdot \mathrm{h}^{-1}\right)=0.12 A_{R}+0.14 A_{T h}+0.0096 A_{K}
$$

where $A_{R}, A_{T h}$ and $A_{K}$ are activity concentrations of ${ }^{226} \mathrm{Ra},{ }^{232} \mathrm{Th}$ and ${ }^{40} \mathrm{~K}$ in Bq. $\mathrm{kg}^{-1}$, respectively. To estimate the annual effective dose account must be taken of the conversion coefficient from the absorbed dose in air to the effective dose and the occupancy factor (UNSCEAR, 2000). The annual effective dose, $E$, due to gamma radiation from building materials is calculated as (EC, 1999)

$$
E=0.7 \mathrm{~Sv} \cdot \mathrm{Gy}^{-1} \times 7000 \mathrm{~h} \times D
$$

where $0.7 \mathrm{~Sv} \cdot \mathrm{Gy}^{-1}$ is the conversion coefficient from the absorbed dose in air to the effective dose and $7000 \mathrm{~h}$ is annual exposure time. From Table III, the mean absorbed dose rate varied from 0.025 (Mol) to $0.035 \mu \mathrm{Gy} \cdot \mathrm{h}^{-1}$ (Setraco) and the mean annual effective dose varied from $0.12(\mathrm{Mol})$ to $0.17 \mathrm{mSv}$ (Setraco and Serena). The results of the annual effective dose obtained in this study did not exceed the limits defined in EC (1999).

\section{Conclusion}

In view of the concern about the radioactivity contents of building materials, activity concentrations of naturally occurring radionuclides in granite samples collected from Ondo State, Nigeria, were determined employing gamma-ray spectrometry. The activity concentrations of ${ }^{226} \mathrm{Ra},{ }^{232} \mathrm{Th}$ and ${ }^{40} \mathrm{~K}$ were in the range of 16.7(6.4) and 85.4(23.0), 62.4(10.1) and 113.6(7.6), and 1315(136) and 1551(84) Bq. $\mathrm{kg}^{-1}$, respectively. The radium equivalent activities of all the samples were below the maximum recommended limit of $370 \mathrm{~Bq} \cdot \mathrm{kg}^{-1}$. The results obtained for the external hazard index and the activity concentration index were also below the recommended maximum limits. The mean absorbed dose rate and annual effective dose ranged from 0.025 to $0.035 \mu \mathrm{Gy} \cdot \mathrm{h}^{-1}$ and 0.12 to $0.17 \mathrm{mSv}$, respectively. From the results obtained in this study, it can be concluded that the granite samples from Ondo State, Nigeria, do not pose any significant radiation hazard when used for construction of dwellings.

\section{REFERENCES}

Abd El-Naby H.H., Saleh G.M. (2003) Radioelement distribution in the Proterozoic granites and associated pegmatites of Gabal El Fereyid area, southeastern desert Egypt, Appl. Radiat. Isotop. 59, 289-299.

Ademola J.A., Atare E.E. (2010) Radiological assessment of natural radionuclides in soil within and around crude oil flow and gas compression stations in the Niger Delta, Nigeria, Radioprotection 45, 219-227. 
Anjos R.M., Veiga R., Soares T., Santos A.M.A., Aguiar J.G., Frascá M.H.B.O, Brage J.A.P., Uzêda D., Mangia L., Facure A., Mosquera B., Carvalho C., Gomes P.R.S. (2005) Natural radionuclide distribution in Brazilian commercial granites, Radiat. Meas. 39, 245-353.

Arafa W. (2004) Specific activity and hazards of granite samples collected from Eastern Desert of Egypt, J. Environm. Radioact. 75, 315-327.

Asghar M., Tufail M., Sabiha-Javied, Abid A., Waqas M. (2008) Radiological implications of granite of northern Pakistan, J. Radiol. Prot. 28, 387-398.

Beretka J., Mathew P.J. (1985) Natural radioactivity of Australian building materials, industrial wastes and by-products, Health Phys. 48, 87-95.

Chen C.-J., Lin Y.-M. (1996) Assessment of building materials for compliance with regulation of ROC, Environm. Intern. 22, 221-226.

DIH (1986) Department of Industrial Hygiene, Radiological Health Protection Standards for Building Materials GB6566-86. Department of Industrial Hygiene, Beijing.

EC (1999) European Commission, Radiological Protection Principles concerning the Natural Radioactivity of Building Materials, Radiation Protection 112.

El-Arabi A.M. (2007) Ra, Th, K concentrations in igneous rocks from eastern desert Egypt and its radiological implications, Radiat. Meas. 42, 94-100.

Farai I.P., Ademola J.A. (2005) Radium equivalent activity concentrations in concrete building blocks in eight cities in Southwestern Nigeria, J. Environm. Radioact. 79, 119-125.

Krieger R. (1981) Radioactivity of construction materials, Betonwerk Fertigteil-Tech. 47, 468-473.

Krisiuk E.M., Tarasov S.I., Shanov V.P., Shalak N.I., Lisachenko E.P., Gomelsky L.G. (1971) A Study of Radioactivity in Building Materials. Research Institute for Radiation Hygiene, Leningrad.

Krstić D., Nikezić D., Stevanović N., Vučić D. (2007) Radioactivity of some domestic and imported building materials from south eastern Europe, Radiat. Meas. 42, 1731-1736.

Lindell B. (1984) A radon control programme in theory and practice, Radiat. Prot. Dosim. 7, 417-425.

Mamont-Cleisla K., Gwiazdowski B., Biernacka M., Zak A. (1981) Radioactivity in building materials in Poland, Proc. 2nd Special Symp. On Natural Radiation Environment (Bombay, January), pp. 551-556. Wiley Eastern, New Delhi.

Ménager M.T., Heath M.J., Ivanovich M., Montjotin C., Barillon C.R., Camp, J., Hasler S.E. (1993) Migration of uranium from uranium-mineralised fractures into rock matrix in granite: implications for radionuclide transport around a radioactive waste repository, Radiochimica Acta 66/67, 47-83.

Orgun Y., Altinsoy N. (2005) Natural radioactivity levels in granitic plutons and groundwaters in southeast part of Eskisehir, Turkey, Appl. Radiat. Isotop. 63, 267-275.

Pavlidou S., Koroneos A., Papastefanou C., Christofides G., Stoulos S., Vavelides M. (2006) Natural radioactivity of granites used as building materials, J. Environm. Radioact. 89, 48-60.

Tzortzis M. (2003) Gamma radiation measurements and dose rates in commercially-used natural tiling rock (granites), J. Environm. Radioact. 70, 223-235.

UNSCEAR (1993) United Nations Scientific Committee on the Effects of Atomic Radiation, Sources and Effects of Ionizing Radiation, Report to the General Assembly. United Nations, New York.

UNSCEAR (2000) United Nations Scientific Committee on the Effects of Atomic Radiation. Sources and Effects of Ionizing Radiation, Report to the General Assembly, with scientific annexes, Vol. I: Sources. United Nations, New York. 